\title{
Scenario Based Ranking of Usability Attributes
}

\author{
K. Paithankar ${ }^{1}$, Dr. M. Ingle ${ }^{2}$ \\ ${ }^{I}$ (Indore Institute of Computer Application, Indore, India, \\ ${ }^{2}$ (School of Computer Science and Information Technology, DAVV, Indore, India,
}

\begin{abstract}
During the usability evaluation process, the impact and behavior of each usability attribute may vary in various software projects and thus instantiates to prioritize the usability attributes involved in the usable software. It has been observed that scenario based evaluation proves to be the best approach for dealing with software development related qualities. Scenarios may provide an excellent manner of synthesizing behavior of individual usability attribute in a common view facilitating easy assessment of these attributes. Therefore, scenarios have been used as the strong tool for evaluating some issues related to usability. In this paper, we propose a Scenario Based Ranking Method (SBRM) for computing the ranks of usability attributes. With user satisfaction/ acceptance being the primary measure, $S B R M$ will prove to be a useful means for ranking usability attributes. It will be a step towards providing measures of usability, improvement in usable software development process subsequently. Especially, $S B R M$ will be useful for incorporating usability attributes with preferences during the process of usable software development.
\end{abstract}

Key words - Ranking, Scenarios, Software Projects, Usability Attributes

\section{INTRODUCTION}

Usability attributes play vital role in defining, attaining and confirming the usability of software $[1,2]$. Each of the usability attribute influences a typical characteristic associated with software $[3,4,5,6,7]$. Literature reveals that the impact of each usability attribute in various softwares may vary during the usability evaluation process $[10,11,12,13,14]$. Thus, it instantiates to prioritize the usability attributes involved in the software [15]. The product-based usability evaluation, indeed involves ranking usability attributes up to some extent with coverage of limited attributes [16, 17, 18]. It has been observed that for assessing quality attributes scenario based, simulation, mathematical modeling and experience based reasoning approaches have been used [19]. The subjective comparison of these approaches suggests that scenario based evaluation is the best approach for dealing with software development related qualities. Moreover, development related qualities are generally easily assessed using scenarios. This assessment process evolves by defining set of scenarios for each usability attribute, manually executing the scenarios considering usability issues associated with development for each usability attribute, interpreting the result subsequently [20]. However, scenarios may provide an excellent manner of synthesizing behavior of individual attribute in a common view.

Scenarios have been used as the strong tool for evaluating some issues related to usability. We propose a Scenario Based Ranking Method (SBRM) for computing the ranks of usability attribute in this paper. The related important

terminology has been reviewed in Section 2. Section 3 discusses stepwise description of our proposed SBRM. In Section 4, four case studies have been presented to focus on the working of $S B R M$ along with the results. Finally, we conclude with the concluding remarks in Section 5.

\section{RELATED TERMINOLOGY}

We review some important terms used in SBRM for computation of ranks of usability attributes.

\section{Software Project}

A software project is a set of interrelated tasks executed systematically to produce software catering the specific needs of users. It is denoted as a triplet $S_{\mathrm{i}} T_{\mathrm{j}} D_{\mathrm{k}}$, where $\left(S_{\mathrm{i}} ; \mathrm{i}=1, \ldots, \mathrm{p}, T_{\mathrm{j}} ; \mathrm{j}=1, \ldots, \mathrm{q}\right.$ and $\left.D_{\mathrm{k}} ; \mathrm{k}=1, \ldots, \mathrm{r}\right)$ represent project size of $\mathrm{p}$ types, project type of q size and project development approach of $r$ types respectively. Thus, a domain contains $p^{*} q^{*} \mathrm{r}$ software projects here.

\section{Usability Attributes}

A usability attribute possesses the functional characteristic of software and hence is associated with a software project also. Pertaining to a software project, these attributes are denoted by $A_{\mathrm{t}} ; \mathrm{t}=1, \ldots, \mathrm{n}$.

\section{Level of Influence}

It is a qualitative measure to indicate the impact of any kind of parameter in a project $S_{\mathrm{i}} T_{\mathrm{j}} D_{\mathrm{k}}$ on the associated usability attributes. Let there be $\mathrm{x}$ number of levels of influence considered in developing a software project, then these are denoted by $I_{\mathrm{m}}, \mathrm{m}=1, \ldots, \mathrm{x}$; stating that $I_{1}$ may be considered as insignificant level of influence, $I_{2}$ moderate, $I_{3}$ average, $I_{4}$ significant and $I_{5}$ highly significant level of influence etc.

\section{Weight}

The magnitude of influence level of a project parameter on usability attribute is termed as weight of the concerned influence level. Each level of influence $\left(I_{\mathrm{m}}, \mathrm{m}=1, \ldots, \mathrm{v}\right)$ 
is mapped with weights $\left(\mathrm{w}_{1}, \mathrm{w}_{2}, \ldots, \mathrm{w}_{\mathrm{v}}\right)$ quantitatively in such a manner that sum of the weights should be equal to1.

\section{Scenario}

A scenario is a synthetic description of an event or series of actions and events that forms the basis of a fully improvised performance [22]. Its purpose is to list a combination of events that describe how a situation might occur in future. For example, "whether a group of users are able to perform the operations on a software successfully or need training" may be considered as a scenario.

\section{SCENARIO BASED RANKING METHOD (SBRM)}

$S B R M$ is an empirical method that uses mainly scenarios for ranking of usability attributes in software projects. We discuss the step as follows:

\section{Step 1: Identification of Software Projects.}

Initially, configure the domain of software projects $S_{\mathrm{i}} T_{\mathrm{j}} D_{\mathrm{k}}$, of size $\left(\mathrm{p}^{*} \mathrm{q}^{*} \mathrm{r}\right)$.

\section{Step 2: Identification of Scenarios.}

Determine all possible aspects related to core properties and behavior of each usability attribute extended in a project uniquely and formally to define scenarios of each usability attribute.

\section{Step 3: Assessment of Scenarios.}

Endorse scenarios for each of the usability attributes in each project. The number pertaining to the endorsed scenarios are termed as accepted number of scenarios for that usability attribute.

\section{Step 4: Computation of Level of Acceptance.}

Level of Acceptance $(L A)$ of a usability attribute $A_{\mathrm{n}}$ in a project $S_{\mathrm{i}} T_{\mathrm{j}} D_{\mathrm{k}}$ is computed as follows:

$$
L A\left(S_{\mathrm{i}} T_{\mathrm{j}} D_{\mathrm{k}}, A_{\mathrm{n}}\right)=\frac{\left(\text { No. of Accepted Scenarios for }-A_{\mathrm{n}}\right)}{\text { Total no. of Scenarios of } A_{\mathrm{n}}}
$$

such that $\quad 0 \leq L A\left(S_{\mathrm{i}} T_{\mathrm{j}} D_{\mathrm{k}}, A_{\mathrm{n}}\right) \leq 1$

\section{Step 5: Estimation of Project Influence.}

Project Influence $\left(P I_{s}\right)$ is referred as the overall influence of project parameters on a usability attribute $A_{\mathrm{n}}$ in a project $S_{\mathrm{i}} T_{\mathrm{j}} D_{\mathrm{k}}$ using a specific scheme of weights $s$. Mathematically it is computed as

$$
P I_{s}\left(S_{\mathrm{i}} T_{\mathrm{j}} D_{\mathrm{k}}, A_{\mathrm{n}}\right)=\mathrm{w}_{\mathrm{i}}+\mathrm{w}_{\mathrm{j}}+\mathrm{w}_{\mathrm{k}}
$$

such that $\alpha \leq P I_{s}\left(S_{\mathrm{i}} T_{\mathrm{j}} D_{\mathrm{k}}, A_{\mathrm{n}}\right) \leq \beta$,

where, $w_{i}, w_{j}$ and $w_{k}$ represent the weights of influence level of size, type and development approach respectively associated with attribute $A_{\mathrm{n}}$ in project $S_{\mathrm{i}} T_{\mathrm{j}} D_{\mathrm{k}}$

and

$$
\alpha=3 * \max \left(\mathrm{w}_{1}, \ldots, \mathrm{w}_{\mathrm{v}}\right) \text { and } \beta=3 * \min \left(\mathrm{w}_{1}, \ldots, \mathrm{w}_{\mathrm{v}}\right)
$$

as our projects are defined in terms of triplets.

\section{Step 6: Computation of Usability Influence.}

Usability Influence $(U I)$ of an attribute $A_{\mathrm{n}}$, in some project $S_{\mathrm{i}} T_{\mathrm{j}} D_{\mathrm{k}}$ is computed as:

$$
U I\left(S_{\mathrm{i}} T_{\mathrm{j}} D_{\mathrm{k}}, A_{\mathrm{n}}\right)=L A\left(S_{\mathrm{i}} T_{\mathrm{j}} D_{\mathrm{k}}, A_{\mathrm{n}}\right) * P I_{s}\left(S_{\mathrm{i}} T_{\mathrm{j}} D_{\mathrm{k}},-A_{\mathrm{n}}\right)
$$

Step 7: Evaluation of Ranks of Usability Attributes. Finally, Overall Influence $(O I)$ of usability on each of the n usability attribute (i.e. $A_{\mathrm{t}}, \mathrm{t}=1 \ldots, \mathrm{n}$ ) in all software projects $S_{\mathrm{i}} T_{j} D_{\mathrm{k}}$ is computed as

$$
O I\left(A_{1}\right)=\left[\sum_{\mathrm{i}=1}^{\mathrm{p}} \sum_{\mathrm{j}=1}^{\mathrm{q}} \underset{\mathrm{k}=1}{\mathrm{r}} \underset{\mathrm{r}}{U}\left(S_{\mathrm{i}} T_{\mathrm{j}} D_{\mathrm{k}}, A_{\mathrm{t}}\right)\right] / \mathrm{p} * \mathrm{q} * \mathrm{r} \quad-(4)
$$

The usability attribute with lowest value of $O I$ is assigned the highest rank as 1 , subsequently the next rank and at last the usability attribute with highest value of $O I$ is assigned the lowest rank as $\mathrm{n}$.

\section{CASE STUDIES AND RESULTS}

We have configured twenty four projects with three project parameters as; project size (small $S_{1}$, intermediate $S_{2}$, medium $S_{3}$, large $S_{4}$ ), project type (organic $T_{1}$, semidetached $T_{2}$, embedded $T_{3}$ ) and project development approach (procedure oriented $D_{1}$, object oriented $D_{2}$ ) to compute ranks of twelve usability attributes using SBRM. The usability attributes are namely; access control $\left(A_{1}\right)$, adaptability $\left(A_{2}\right)$, affect $\left(A_{3}\right)$, customizability $\left(A_{4}\right)$, efficiency $\left(A_{5}\right)$, helpfulness $\left(A_{6}\right)$, learnability $\left(A_{7}\right)$, operability $\left(A_{8}\right)$, practicability $\left(A_{9}\right)$, resilience $\left(A_{10}\right)$, unambiguity $\left(A_{11}\right)$ and validity $\left(A_{12}\right)$. The scenarios have been defined on the basis of possessed properties of these attributes. We have assumed four influence levels of project parameters as; insignificant $\left(I_{1}\right)$ moderate $\left(I_{2}\right)$, average $\left(I_{3}\right)$ and significant influence $\left(I_{4}\right)$. The weights $\mathrm{w}_{1}, \mathrm{w}_{2}, \mathrm{w}_{3}$ and $\mathrm{w}_{4}$ have been assigned to these influence levels in ascending order in such a manner that sum of the weights is equal to 1 [23].

In our study, we have examined SBRM using four cases based on number of acceptance of scenarios of each usability attribute such as (i) acceptance of random number of scenarios (ii) acceptance of all the scenarios (iii) acceptance of more than $50 \%$ scenarios and (iv) acceptance of less than $50 \%$ scenarios respectively. Forty seven schemes of weights of influence levels of our interest have been used to compute the ranks in each case.

\section{Case I- Acceptance of Random Number of Scenarios}

Using SBRM, we have computed the ranks of each of the twelve usability attributes using forty seven schemes of weights of influence levels. Table-1(a) and Table-1(b) 
show the results for few schemes only here but the trend depicts that practicability, operability, learnability, customizability and resilience possess the same ranks as $1,2,3,8$ and 12 respectively in all schemes. On the other hand, ranks of other usability attributes access control, adaptability, affect, efficiency, validity vary in some schemes with very low deviation due to the perception of users about the usability attributes during project development. Adaptability seems to be relatively challenging issue during development in this case.

\section{Case II- Acceptance of All Scenarios}

In this case, the ranks of usability attributes practicability, operability, learnability, affect, access control and resilience do not differ at all in all schemes whereas other attributes possess varying ranks as shown in Table-1(a) and Table-1(b). With full user satisfaction and consistent role of majority of usability attributes, the projects suffer from the uncertainties related to adaptability, customizability and efficiency in this case.

\section{Case III- Acceptance of More Than $50 \%$ Scenarios}

Here, practicability, access control, efficiency and resilience possess the same rank in all the schemes as depicted in Table-1(a) and Table-1(b). The ranks of other attributes such as operability, learnability, helpfulness and validity have very low variation. Similarly, marginal variation has been observed in the ranks of usability attributes such as adaptability, affect, customizability and un-ambiguity. Thus, we observe here that there exist three categories of usability attributes such as those contributing consistently, playing part with minor uncertainties and adding major uncertainties to the project.

\section{Case IV-Acceptance of Less Than $50 \%$ Scenarios}

As shown in Table-1(a) and Table-1(b), the ranks computed for practicability, resilience and helpfulness are same in various schemes. But the ranks of access control, learnability, un-ambiguity, validity change with a fair difference whereas for adaptability, affect, customizability, efficiency and operability vary with a noticeable difference. It is clear that the projects in this case suffer from low user satisfaction and thus are very critical for development from developers' viewpoint.

\section{CONCLUSION}

Our Scenario Based Ranking Method (SBRM) is primarily based on the use of scenarios of usability attributes in order to compute ranks of usability attributes. Scenarios included information about goals, expectations, motivations, actions and reactions. It provides subjective as well as objective way to investigate usability attributes and capture the rationale behind importance of usability attributes. SBRM is especially useful for incorporating usability attributes with preferences during the process of usable software development. In general, ranking usability attributes will tend to focus on usability evaluation and of great support to practitioners while software development as well.

\section{REFERENCES}

[1] Paithankar, K. and Ingle, M., Reviewing Software Quality Attributes Classification in Perspective of Usability, PCTE journal of computer Science, Volume 7, Issue 1, January-June, 2010, pp 107-117.

[2] Khosravi , K. and Yann-Ga“el Gu'eh'eneuc, On Issues with Software Quality Model, Group of Open and Distributed Systems, Experimental Software Engineering Department of Informatics and Operations Research University of Montreal, Quebec, Canada, pp 70-83.

[3] Sauro, J. and Kindlund, E., Making Sense of Usability Metrics: Usability and Six Sigma, UPA Conference, 2005, pp P.1-P.10.

[4] Donyaee, M. K..; Seffah, A. and Rilling, J., Benchmarking Usability of Early Designs Using Predictive Metrics, IEEE, 2007, pp 2514-2519.

[5] Rauterberg, M., How to Measure and to Quantify Usability Attributes of Man-Machine Interfaces, Fifth International Workshop on Robot and Human Communication, 1996, pp 262-267.

[6] Winter, J.; Rönkkö, K. and Hellman, M., Reporting Usability Metrics Experiences, IEEE, ICSE workshop, 2009, pp108-115.

[7] Burgin, M.; Lee, H. K. and Debnath, N., Software Technological Roles, Usability, and Reusability, IEEE, 2004, pp 210-214.

[8] Seffah, A.; Kececi, N. and Donyaee, M., Quim: A Framework for Quantifying Usability Metrics in Software Quality Model, IEEE, 2001, pp 311318.

[9] Andreas, Lecerof and Fabio, Paternò, Automatic Support for Usability Evaluation, IEEE transactions on software engineering, Volume 24, Issue 10, October, 1998, pp 863-888.

[10] Cofofrei, P. and Luchian, H., Statistical Dependency, IEEE, 1996, pp 32-41.

[11] Alinaghi, A.; Ghoroghi,C.; Sabouri, A. and Basseda R., A Framework for Dependency Evaluation of the Agent oriented Methodologies Work Flows, Third IEEE International Symposium on Theoretical Aspects of Software Engineering, 2009, 289-290.

[12] Nielsen, J., Usability Engineering, Boston Academic Press, 1993.

[13] Nielsen, J., Usability Engineering Life Cycle, IEEE Computer Society, Volume 25, Issue 3, March, 1992, pp 12-22.

[14] Nigel, B., and Motoei, A., Quality in Use: Incorporating Human Factors into the software life cycle, Third IEEE International Software Engineering Standards Symposium and Forum' Emerging International Standards', ISESS97, June1-6, 1997, pp 169-179.

[15] Paithankar, K. and Ingle, M., A Novel Approach to Ranking Usability Attributes, International Journal 
of Engineering Research and Application (IJERA), Volume 2, Issue 2, March-April, 2012, pp 11971202.

[16] Sulaiman, J.; Zulkifli, T; Ibrahim, K.S.K. and Noor, N.K.M., Implementing Usability Attributes in E-Learning System using Hybrid Heuristics, International Conference on Information and Multimedia Technology (ICIMT), 2009, pp 189193.

[17] Granic, A. and Glavinic, V., Usability Evaluation Issues for Computerized Educational Systems, Eleventh Mediterranean Electro Technical Conference, MELECON, 2002, pp 558- 562.

[18] Sutcliff, A., A Technique Combination Approach to Requirements Engineering, Third International Symposium on Requirements Engineering, 1997, pp 65-74.

[19] Bangtsson, P. and Bosch, J, Scenario Based Software Architecture Reengineering, IEEE
International Conference on Software Reuse, 1998 pp 308-317.

[20] Mavin, A. and Maiden, N., Determining SocioTechnical Systems Requirements: Experiences with Generating and Walking through Scenarios, Eleventh IEEE International Conference on Requirements Engineering, 2003, pp 213-222.

[21] Kurosu, M. and Kashimura, K.,Determinants of the Apparent Usability, IEEE International Conference on Systems, Man and Cybernetics, Intelligent Systems for the $21^{\text {st }}$ Century, Volume 2, October 22-25, 1995, pp1509-1514.

[22] http://en.wikipedia.org/wiki/Scenario.

[23] Paithankar, K. and Ingle, M., Influence of Project Parameters on Usability Attributes in Software Projects, International Conference on Advanced Sciences, Engineering and Information Technology (ICASEIT), Kuala Lumpur, Malaysia, 14-15 January, 2011, pp 268-272.

Table-1(a): Ranks of Some Usability Attributes using Different Schemes of Weights in Four Cases

\begin{tabular}{|c|c|c|c|c|c|c|c|c|c|c|c|c|c|c|c|c|c|c|c|c|c|c|c|c|c|c|c|}
\hline \multirow{2}{*}{\multicolumn{4}{|c|}{$\begin{array}{c}\text { Schemes of } \\
\text { Weights of } \\
\text { Influence Levels }\end{array}$}} & \multirow{2}{*}{\multicolumn{4}{|c|}{$\begin{array}{c}\begin{array}{c}\text { Access } \\
\text { Control }\left(\mathbf{A}_{1}\right)\end{array} \\
\text { CASE }\end{array}$}} & \multirow{2}{*}{\multicolumn{4}{|c|}{$\begin{array}{c}\begin{array}{c}\text { Adaptability } \\
\left(\mathbf{A}_{2}\right)\end{array} \\
\text { CASE }\end{array}$}} & \multirow{2}{*}{\multicolumn{4}{|c|}{$\begin{array}{c}\text { Affect }\left(\mathbf{A}_{3}\right) \\
\text { CASE }\end{array}$}} & \multirow{2}{*}{\multicolumn{4}{|c|}{\begin{tabular}{|c|}
$\begin{array}{c}\text { Customizabil } \\
\text { ity }\left(\mathrm{A}_{4}\right)\end{array}$ \\
CASE
\end{tabular}}} & \multirow{2}{*}{\multicolumn{4}{|c|}{$\begin{array}{c}\begin{array}{c}\text { Efficiency } \\
\left(\mathbf{A}_{5}\right)\end{array} \\
\text { CASE } \\
\end{array}$}} & \multirow{2}{*}{\multicolumn{4}{|c|}{$\begin{array}{c}\text { Helpfulness } \\
\left(\mathrm{A}_{6}\right)\end{array}$}} \\
\hline & & & & & & & & & & & & & & & & & & & & & & & & & & & \\
\hline $\mathbf{w}_{1}$ & $\mathbf{w}_{\mathbf{2}}$ & $\mathbf{w}_{\mathbf{3}}$ & $\mathbf{w}_{4}$ & I & $\begin{array}{l}\text { I } \\
\text { I }\end{array}$ & \begin{tabular}{l|}
$\mathbf{I}$ \\
$\mathbf{I}$ \\
$\mathbf{I}$
\end{tabular} & $\begin{array}{l}\text { I } \\
\text { V }\end{array}$ & I & $\begin{array}{l}\text { I } \\
\text { I }\end{array}$ & \begin{tabular}{l|}
$\mathbf{I}$ \\
$\mathbf{I}$ \\
$\mathbf{I}$
\end{tabular} & I & $\mathbf{I}$ & $\begin{array}{l}\mathbf{I} \\
\mathbf{I}\end{array}$ & \begin{tabular}{l|}
$\mathbf{I}$ \\
$\mathbf{I}$ \\
$\mathbf{I}$
\end{tabular} & $\begin{array}{c}\text { I } \\
\text { V }\end{array}$ & I & $\begin{array}{l}\mathbf{I} \\
\mathbf{I}\end{array}$ & \begin{tabular}{l|}
$\mathbf{I}$ \\
$\mathbf{I}$ \\
$\mathbf{I}$
\end{tabular} & $\begin{array}{l}\mathbf{I} \\
\mathbf{V}\end{array}$ & $\mathbf{I}$ & $\begin{array}{l}\mathbf{I} \\
\mathbf{I}\end{array}$ & \begin{tabular}{l|}
$\mathbf{I}$ \\
$\mathbf{I}$ \\
$\mathbf{I}$
\end{tabular} & $\begin{array}{l}\mathbf{I} \\
\mathbf{V}\end{array}$ & $\mathbf{I}$ & I & $\begin{array}{l}\text { I } \\
\text { I } \\
\text { I }\end{array}$ & I \\
\hline 0 & $\begin{array}{c}0 . \\
05\end{array}$ & 0.1 & $\begin{array}{l}0 . \\
85\end{array}$ & 4 & 5 & 5 & 5 & 1 & $\begin{array}{l}1 \\
1\end{array}$ & $\begin{array}{l}1 \\
1 \\
\end{array}$ & 9 & 5 & 4 & 4 & 4 & 8 & 8 & 8 & 7 & 6 & 6 & 6 & 6 & $\begin{array}{l}1 \\
0\end{array}$ & $\begin{array}{l}1 \\
0\end{array}$ & $\begin{array}{l}1 \\
0\end{array}$ & 1 \\
\hline 0 & $\begin{array}{c}0 . \\
1\end{array}$ & 0.3 & $\begin{array}{c}0 . \\
06\end{array}$ & 5 & 5 & 5 & 5 & 1 & 1 & $\begin{array}{l}1 \\
0\end{array}$ & 9 & 4 & 4 & 4 & 4 & 8 & 8 & 8 & 6 & 7 & 7 & 6 & 8 & $\begin{array}{l}1 \\
0\end{array}$ & $\begin{array}{l}1 \\
1\end{array}$ & $\begin{array}{l}1 \\
1\end{array}$ & $\begin{array}{l}1 \\
1\end{array}$ \\
\hline 0 & $\begin{array}{l}0 . \\
25\end{array}$ & $\begin{array}{c}0.3 \\
5\end{array}$ & $\begin{array}{c}0 . \\
4\end{array}$ & 4 & 5 & 5 & 5 & 9 & 8 & 7 & 7 & 5 & 4 & 2 & 6 & 8 & 1 & 9 & 4 & 7 & 7 & 6 & 6 & $\begin{array}{l}1 \\
1\end{array}$ & $\begin{array}{l}1 \\
1\end{array}$ & $\begin{array}{l}1 \\
1\end{array}$ & $\begin{array}{l}1 \\
1\end{array}$ \\
\hline $\begin{array}{c}0 . \\
05\end{array}$ & $\begin{array}{c}0 . \\
1\end{array}$ & $\begin{array}{c}0.1 \\
5\end{array}$ & $\begin{array}{c}0 . \\
7\end{array}$ & 4 & 5 & 5 & 5 & 1 & 1 & $\begin{array}{l}1 \\
0\end{array}$ & 9 & 5 & 4 & 4 & 4 & 8 & 8 & 8 & 6 & 6 & 6 & 6 & 7 & $\begin{array}{l}1 \\
0\end{array}$ & $\begin{array}{l}1 \\
0\end{array}$ & $\begin{array}{l}1 \\
1\end{array}$ & $\begin{array}{l}1 \\
1\end{array}$ \\
\hline $\begin{array}{c}0 . \\
05\end{array}$ & $\begin{array}{c}0 . \\
15\end{array}$ & $\begin{array}{c}0.2 \\
5\end{array}$ & $\begin{array}{l}0 . \\
55\end{array}$ & 4 & 5 & 5 & 5 & 1 & 1 & $\begin{array}{l}1 \\
0\end{array}$ & 9 & 5 & 4 & 4 & 4 & 8 & 8 & 8 & 6 & 7 & 7 & 6 & 8 & $\begin{array}{l}1 \\
0\end{array}$ & 1 & 1 & $\begin{array}{l}1 \\
1\end{array}$ \\
\hline $\begin{array}{c}0 . \\
05\end{array}$ & $\begin{array}{l}0 . \\
25\end{array}$ & 0.3 & $\begin{array}{c}0 . \\
4\end{array}$ & 4 & 5 & 5 & 5 & 1 & 8 & 8 & 7 & 5 & 4 & 2 & 6 & 8 & 9 & 7 & 3 & 7 & 7 & 6 & 9 & $\begin{array}{l}1 \\
0\end{array}$ & $\begin{array}{l}1 \\
1\end{array}$ & $\begin{array}{l}1 \\
1\end{array}$ & $\begin{array}{l}1 \\
1\end{array}$ \\
\hline $\begin{array}{c}0 . \\
1\end{array}$ & $\begin{array}{l}0 . \\
15\end{array}$ & 0.2 & $\begin{array}{l}0 . \\
55\end{array}$ & 4 & 5 & 5 & 6 & 1 & $\begin{array}{l}1 \\
1\end{array}$ & $\begin{array}{l}1 \\
0\end{array}$ & 9 & 5 & 4 & 4 & 5 & 8 & 8 & 8 & 4 & 6 & 6 & 6 & 7 & $\begin{array}{l}1 \\
0\end{array}$ & $\begin{array}{l}1 \\
0\end{array}$ & $\begin{array}{l}1 \\
1\end{array}$ & $\begin{array}{l}1 \\
1\end{array}$ \\
\hline $\begin{array}{c}0 . \\
1\end{array}$ & $\begin{array}{l}0 . \\
2\end{array}$ & $\begin{array}{c}0.2 \\
5\end{array}$ & $\begin{array}{c}0 . \\
45\end{array}$ & 4 & 5 & 5 & 5 & 1 & & 9 & 8 & 5 & 4 & 3 & 6 & 8 & 8 & 7 & 4 & 6 & 6 & 6 & 9 & $\begin{array}{l}1 \\
0\end{array}$ & $\begin{array}{l}1 \\
1\end{array}$ & $\begin{array}{l}1 \\
1\end{array}$ & $\begin{array}{l}1 \\
1\end{array}$ \\
\hline $\begin{array}{c}0 . \\
1\end{array}$ & $\begin{array}{c}0 . \\
25\end{array}$ & 0.3 & $\begin{array}{l}0 . \\
35\end{array}$ & 4 & 5 & 5 & 6 & $\begin{array}{l}1 \\
1\end{array}$ & 8 & 7 & 4 & 5 & 4 & 2 & 7 & 8 & $\begin{array}{l}1 \\
0\end{array}$ & 8 & 2 & 7 & 7 & 6 & 9 & $\begin{array}{l}1 \\
0\end{array}$ & $\begin{array}{l}1 \\
1\end{array}$ & $\begin{array}{l}1 \\
1\end{array}$ & $\begin{array}{l}1 \\
1\end{array}$ \\
\hline $\begin{array}{c}0 . \\
15\end{array}$ & $\begin{array}{l}0 . \\
2\end{array}$ & $\begin{array}{c}0.2 \\
5\end{array}$ & $\begin{array}{c}0 . \\
4\end{array}$ & 4 & 5 & 5 & 6 & 1 & 0 & 9 & 8 & 5 & 4 & 2 & 5 & 8 & 8 & 7 & 2 & 7 & 7 & 6 & 9 & $\begin{array}{l}1 \\
0\end{array}$ & $\begin{array}{l}1 \\
1\end{array}$ & $\begin{array}{l}1 \\
1\end{array}$ & $\begin{array}{l}1 \\
1\end{array}$ \\
\hline $\begin{array}{c}0 . \\
15\end{array}$ & $\begin{array}{l}0 . \\
2\end{array}$ & 0.3 & $\begin{array}{l}0 . \\
35\end{array}$ & 4 & 5 & 5 & 7 & 1 & & 9 & 6 & 5 & 4 & 2 & 5 & 8 & 9 & 8 & 2 & 7 & 8 & 6 & $\begin{array}{l}1 \\
0\end{array}$ & $\begin{array}{l}1 \\
0\end{array}$ & $\begin{array}{l}1 \\
1\end{array}$ & $\begin{array}{l}1 \\
1\end{array}$ & $\begin{array}{l}1 \\
1\end{array}$ \\
\hline
\end{tabular}


Table-1(b): Ranks of Other Usability Attributes using Different Schemes of Weights in Four Cases

\begin{tabular}{|c|c|c|c|c|c|c|c|c|c|c|c|c|c|c|c|c|c|c|c|c|c|c|c|c|c|c|c|}
\hline \multicolumn{4}{|c|}{$\begin{array}{c}\text { Schemes of } \\
\text { Weights of } \\
\text { Influence Levels }\end{array}$} & \multirow{2}{*}{\multicolumn{4}{|c|}{$\begin{array}{c}\begin{array}{c}\text { Learnability } \\
\left(\mathbf{A}_{7}\right)\end{array} \\
\mathrm{CASE} \\
\end{array}$}} & \multirow{2}{*}{\multicolumn{4}{|c|}{$\begin{array}{c}\begin{array}{c}\text { Operability } \\
\left(\mathbf{A}_{8}\right)\end{array} \\
\text { CASE } \\
\end{array}$}} & \multirow{2}{*}{\multicolumn{4}{|c|}{\begin{tabular}{|c|}
$\begin{array}{c}\text { Practicabilit } \\
\mathbf{y}\left(\mathbf{A}_{9}\right)\end{array}$ \\
CASE
\end{tabular}}} & \multirow{2}{*}{\multicolumn{4}{|c|}{$\begin{array}{c}\begin{array}{c}\text { Resilience } \\
\left(\mathbf{A}_{\mathbf{1 0}}\right)\end{array} \\
\text { CASE }\end{array}$}} & \multirow{2}{*}{\multicolumn{4}{|c|}{$\begin{array}{c}\begin{array}{c}\text { Un- } \\
\text { ambiguity } \\
\left(\mathrm{A}_{11}\right)\end{array} \\
\text { CASE }\end{array}$}} & \multirow{2}{*}{\multicolumn{4}{|c|}{\begin{tabular}{|c|} 
Validity $\left(\mathbf{A}_{12}\right)$ \\
CASE
\end{tabular}}} \\
\hline \multirow[b]{2}{*}{$\mathbf{w}_{1}$} & \multirow[b]{2}{*}{$\mathbf{w}_{2}$} & \multirow[b]{2}{*}{$\mathbf{w}_{\mathbf{3}}$} & & & & & & & & & & & & & & & & & & & & & & & & & \\
\hline & & & $\mathbf{w}_{4}$ & I & $\begin{array}{l}\mathbf{I} \\
\mathbf{I}\end{array}$ & $\begin{array}{l}\text { I } \\
\text { I } \\
\text { I }\end{array}$ & $\begin{array}{l}\text { I } \\
\text { V }\end{array}$ & $\mathbf{I}$ & I & & $\begin{array}{l}\mathbf{I} \\
\mathbf{V}\end{array}$ & $\mathbf{I}$ & $\begin{array}{l}\text { I } \\
\text { I }\end{array}$ & $\begin{array}{l}\text { I } \\
\text { I }\end{array}$ & I & I & $\begin{array}{l}\mathbf{I} \\
\mathbf{I}\end{array}$ & \begin{tabular}{l|}
$\mathbf{I}$ \\
$\mathbf{I}$ \\
$\mathbf{I}$
\end{tabular} & $\begin{array}{l}\text { I } \\
\text { V }\end{array}$ & I & $\begin{array}{l}\mathbf{I} \\
\mathbf{I}\end{array}$ & $\begin{array}{l}\mathbf{I} \\
\mathbf{I} \\
\mathbf{I}\end{array}$ & $\begin{array}{l}\mathbf{I} \\
\mathbf{V}\end{array}$ & I & $\begin{array}{l}\mathbf{I} \\
\mathbf{I}\end{array}$ & $\begin{array}{l}\mathbf{I} \\
\mathbf{I} \\
\mathbf{I}\end{array}$ & $\begin{array}{l}\text { I } \\
\text { V }\end{array}$ \\
\hline 0 & $\begin{array}{l}0 . \\
05\end{array}$ & 0.1 & $\begin{array}{c}0 . \\
85 \\
\end{array}$ & 3 & 3 & 3 & 3 & 2 & 2 & 2 & 2 & 1 & 1 & 1 & 1 & 1 & 1 & $\begin{array}{l}1 \\
2\end{array}$ & $\begin{array}{l}1 \\
2\end{array}$ & 7 & 7 & 7 & 8 & 9 & 9 & 9 & $\begin{array}{l}1 \\
0\end{array}$ \\
\hline 0 & $\begin{array}{c}0 . \\
1 \\
\end{array}$ & 0.3 & $\begin{array}{c}0 . \\
06 \\
\end{array}$ & 3 & 3 & 3 & 3 & 2 & 2 & 2 & 2 & 1 & 1 & 1 & 1 & 4 & $\begin{array}{l}1 \\
2\end{array}$ & $\begin{array}{l}1 \\
2 \\
\end{array}$ & 1 & 6 & 6 & 7 & 7 & 9 & 9 & 9 & $\begin{array}{l}1 \\
0 \\
\end{array}$ \\
\hline 0 & $\begin{array}{c}0 . \\
25\end{array}$ & $\begin{array}{c}0.3 \\
5\end{array}$ & $\begin{array}{c}0 . \\
4\end{array}$ & 3 & 3 & 4 & 2 & 2 & 2 & 3 & 3 & 1 & 1 & 1 & 1 & $\begin{array}{l}1 \\
2\end{array}$ & 1 & $\begin{array}{l}1 \\
2\end{array}$ & 1 & 6 & 6 & 8 & 8 & 1 & 9 & $\begin{array}{l}1 \\
0\end{array}$ & $\begin{array}{l}1 \\
0\end{array}$ \\
\hline $\begin{array}{c}0 . \\
05\end{array}$ & $\begin{array}{c}0 . \\
1\end{array}$ & $\begin{array}{c}0.1 \\
5\end{array}$ & $\begin{array}{c}0 . \\
7\end{array}$ & 3 & 3 & 3 & 2 & 2 & 2 & 2 & 3 & 1 & 1 & 1 & 1 & 2 & 2 & $\begin{array}{l}1 \\
2\end{array}$ & 2 & 7 & 7 & 7 & 8 & 9 & 9 & 9 & $\begin{array}{l}1 \\
0\end{array}$ \\
\hline $\begin{array}{c}0 . \\
05 \\
\end{array}$ & $\begin{array}{c}0 . \\
15 \\
\end{array}$ & $\begin{array}{c}0.2 \\
5 \\
\end{array}$ & $\begin{array}{c}0 . \\
55 \\
\end{array}$ & 3 & 3 & 3 & 2 & 2 & 2 & 2 & 3 & 1 & 1 & 1 & 1 & 1 & 1 & $\begin{array}{l}1 \\
2 \\
\end{array}$ & 1 & 6 & 6 & 7 & 7 & 9 & 9 & 9 & $\begin{array}{l}1 \\
0 \\
\end{array}$ \\
\hline $\begin{array}{c}0 . \\
05\end{array}$ & $\begin{array}{c}0 . \\
25\end{array}$ & 0.3 & $\begin{array}{c}0 . \\
4\end{array}$ & 3 & 3 & 4 & 2 & 2 & 2 & 3 & 4 & 1 & 1 & 1 & 1 & 2 & $\begin{array}{l}1 \\
2 \\
\end{array}$ & $\begin{array}{l}1 \\
2\end{array}$ & 2 & 6 & 6 & 9 & 8 & 9 & $\begin{array}{l}1 \\
0 \\
\end{array}$ & $\begin{array}{l}1 \\
0\end{array}$ & $\begin{array}{l}1 \\
0\end{array}$ \\
\hline $\begin{array}{c}0 . \\
1 \\
\end{array}$ & $\begin{array}{c}0 . \\
15 \\
\end{array}$ & 0.2 & $\begin{array}{c}0 . \\
55\end{array}$ & 3 & 3 & 3 & 2 & 2 & 2 & 2 & 3 & 1 & 1 & 1 & 1 & $\begin{array}{l}1 \\
2 \\
\end{array}$ & $\begin{array}{l}1 \\
2\end{array}$ & $\begin{array}{l}1 \\
2\end{array}$ & $\begin{array}{l}1 \\
2 \\
\end{array}$ & 7 & 7 & 7 & 8 & 9 & 9 & 9 & $\begin{array}{l}1 \\
0 \\
\end{array}$ \\
\hline $\begin{array}{l}0 . \\
1\end{array}$ & $\begin{array}{l}0 . \\
2 \\
\end{array}$ & $\begin{array}{c}0.2 \\
5\end{array}$ & $\begin{array}{l}0 . \\
45 \\
\end{array}$ & 3 & 3 & 4 & 2 & 2 & 2 & 2 & 3 & 1 & 1 & 1 & 1 & $\begin{array}{l}1 \\
2\end{array}$ & $\begin{array}{l}1 \\
2\end{array}$ & $\begin{array}{l}1 \\
2\end{array}$ & $\begin{array}{l}1 \\
2\end{array}$ & 7 & 7 & 8 & 7 & 9 & 9 & $\begin{array}{l}1 \\
0\end{array}$ & $\begin{array}{l}1 \\
0\end{array}$ \\
\hline $\begin{array}{c}0 . \\
1 \\
\end{array}$ & $\begin{array}{l}0 . \\
25 \\
\end{array}$ & 0.3 & $\begin{array}{c}0 . \\
35 \\
\end{array}$ & 3 & 3 & 4 & 3 & 2 & 2 & 3 & 5 & 1 & 1 & 1 & 1 & $\begin{array}{l}1 \\
2 \\
\end{array}$ & $\begin{array}{l}1 \\
2 \\
\end{array}$ & $\begin{array}{l}1 \\
2 \\
\end{array}$ & $\begin{array}{l}1 \\
2 \\
\end{array}$ & 6 & 6 & 9 & 8 & 9 & 9 & $\begin{array}{l}1 \\
0 \\
\end{array}$ & $\begin{array}{l}1 \\
0 \\
\end{array}$ \\
\hline $\begin{array}{c}0 . \\
15 \\
\end{array}$ & $\begin{array}{l}0 . \\
2\end{array}$ & $\begin{array}{c}0.2 \\
5\end{array}$ & $\begin{array}{c}0 . \\
4 \\
\end{array}$ & 3 & 3 & 4 & 3 & 2 & 2 & 3 & 4 & 1 & 1 & 1 & 1 & $\begin{array}{l}1 \\
2\end{array}$ & $\begin{array}{l}1 \\
2 \\
\end{array}$ & $\begin{array}{l}1 \\
2\end{array}$ & $\begin{array}{l}1 \\
2\end{array}$ & 6 & 6 & 8 & 7 & 9 & 9 & $\begin{array}{l}1 \\
0\end{array}$ & $\begin{array}{l}1 \\
0\end{array}$ \\
\hline $\begin{array}{c}0 . \\
15\end{array}$ & $\begin{array}{l}0 . \\
2 \\
\end{array}$ & 0.3 & $\begin{array}{c}0 . \\
35\end{array}$ & 3 & 3 & 4 & 3 & 2 & 2 &  & 4 & 1 & 1 & 1 & 1 & 2 & $\begin{array}{l}1 \\
2\end{array}$ & $\begin{array}{l}1 \\
2\end{array}$ & $\begin{array}{l}1 \\
2\end{array}$ & 6 & 6 & 7 & 8 & 9 & 7 & $\begin{array}{l}1 \\
0\end{array}$ & 9 \\
\hline
\end{tabular}

